\title{
Influence of meal-feeding on some of the effects of dietary carbohydrate deficiency in rats*
}

\author{
By S. S. AKRABAWI AND J. P. SALJI \\ Department of Food Technology and Nutrition, Faculty of Agricultural Sciences, \\ American University of Beirut, Beirut, Lebanon
}

(Received 20 fune 1972-Accepted 5 December 1972)

\begin{abstract}
I. Experiments were conducted to investigate the effects of feeding rats on a diet based on a mixture of maize oil fatty acids as the only source of non-protein energy (fatty acid diet) and the influence on these effects of giving such a diet in a single daily meal lasting $2 \mathrm{~h}$.

2. In comparison with a triglyceride diet in which the non-protein energy was in the form of maize oil, feeding $a d$ lib. with the fatty acid diet produced no significant changes in bodyweight gain, plasma glucose and plasma ketones concentrations, liver glycogen concentration and protein efficiency ratio.

3. In comparison with the triglyceride diet, meal-feeding with the fatty acid diet produced significantly lower body-weight gain and protein efficiency ratio; moreover, it significantly lowered plasma glucose and liver glycogen concentrations.

4. Rats meal-fed on the fatty acid diet synthesized glucose from protein, as evidenced by the significantly higher liver glycogen concentration detected $6 \mathrm{~h}$ after the meal had been eaten, but the increase was significantly lower than in the animals fed on the triglyceride diet. Also, $6 \mathrm{~h}$ after the meal had been eaten, the amount of meal remaining in the stomach of rats mealfed on the fatty acid diet was significantly higher than in those fed on the triglyceride diet.
\end{abstract}

Studies on the physiological effects of feeding animals on diets based on a mixture of fatty acids as the only source of non-protein energy were first conducted on the chicken by Renner \& Elcombe ( 1964 ). Feeding with such diets resulted in a marked depression of growth rate, which was corrected when the fatty acid diet was supplemented with an amount of glucose or glycerol that was theoretically equivalent to that required for the conversion of fatty acids into triglycerides. In later studies, Brambila $\&$ Hill (1966, 1967) confirmed the growth-depressing effects of such diets in the chicken and further observed that feeding with a fatty acid diet produced hypoglycaemia and lowered liver glycogen concentration. The apparent absorbability of lipid and nitrogen retention in chickens fed on the fatty acid diet werc not altered (Brambila \& Hill, 1966). The $\mathrm{N}$ retained was not used for the promotion of growth as effectively as that of the diet with adequate carbohydrate. This was apparent from the work of Allred \& Roehrig (1970) and Allred (1969) on the chicken, who observed that the changes in the concentration of liver enzymes and metabolites allowed increased utilization of amino acids for glucose synthesis and depleted the available supply of amino acids for the growth of chickens fed on the fatty acid diet.

The possibility of using a fatty acid diet in the evaluation of the glucogenicity of dietary protein in rats was investigated by Akrabawi \& Fill (1970). Using a diet containing $150 \mathrm{~g}$ protein $/ \mathrm{kg}$ they found that protein was about half as effective as

* Authorized for publication as Scientific Paper Series No. I9 I by the Faculty of Agricultural Sciences of the American University of Beirut, Beitut, Lebanon. 
glucose in improving growth, and alleviating hypoglycaemia and ketonaemia. Their work and that of Goldberg (1971), in which he investigated the effect of the fatty acid diet on enzyme concentration in rat liver, also suggested reduced utilization of dietary protein for growth and an increase in its utilization for glucose formation. Another factor in determining the extent to which dietary protein is utilized in functions unrelated to growth is that of the restriction of food consumption in experimental animals to a single meal each day. Leveille \& Hanson (1965, 1966) and Leveille (1967) found that, in comparison to nibbling, the restriction of food consumption by rats to a $2 \mathrm{~h}$ meal daily increased the utilization of amino acids for the formation of lipid and glycogen.

In the study now described some physiological effects of feeding rats on fatty acid diets containing $200 \mathrm{~g}$ casein protein $/ \mathrm{kg}$ and a mixture of maize oil fatty acids as the only source of non-protein energy were studied under $a d l i b$. and meal-feeding conditions. In both investigations, a similar triglyceride diet containing maize oil as the only source of non-protein energy served as the control.

\section{EXPER I MENTAL}

\section{Animals and diets}

Weaned, Sprague-Dawley male rats were obtained from Animal Suppliers (London) Ltd. They were fed on a steck diet for a week $\pm 2 \mathrm{~d}$ until they attained an average weight of $110 \pm 5 \mathrm{~g}$. 'They were then randomized among dietary treatments and housed in individual cages in a temperature-controlled room at $22^{\circ}$; the experimental period was I9 $\pm 2 \mathrm{~d}$. The composition of the control and experimental diets is shown in Table $\mathrm{I}$. These diets differed only in the source of energy: in the triglyceride diet this was supplied by maize oil and in the fatty acid diet by maize oil fatty acids prepared by hydrolysis of maize oil according to the method of Brambila \& Hill (1966). Each diet contained $0.5 \%$ chromic oxide as an indicator for the measurement of the effects of the diets on the rate of stomach emptying. The meal-fed rats were given their diet every day for $2 \mathrm{~h}$ at 08.30 hours. All animals in Expts $1-5$ were killed on the last day of the experiment after 10.30 hours. On the last day of Expt 6, eight of the mealfed rats/treatment were killed 2, 4 and $6 \mathrm{~h}$ after the beginning of feeding. The stomach contents of each rat were collected in a dish, mixed and dried and the $\mathrm{Cr}_{2} \mathrm{O}_{3}$ content was determined. The total amount of $\mathrm{Cr}_{2} \mathrm{O}_{3}$ in the stomach was used to calculate the amount of the meal that was present in the stomach at the specified time. In all cxperiments, the food consumption of each rat was recorded daily and the weight twice weekly. Ten rats/treatment were used in Expts I and 2, twenty in Expts $3^{-} 5$ and twenty-four in Expt 6.

\section{Analytical methods}

Glucose and total ketone bodies in $\mathrm{I} \mathrm{ml}$ plasma were determined on the filtrate from $\mathrm{ZnSO}_{4}-\mathrm{Ba}(\mathrm{OH})_{2}$ precipitation. Glucose was measured by the glucose oxidaseperoxidase method using $o$-dianisidine (Sigma Chemical Co., St Louis, Mo., USA) as the chromogenic oxygen acceptor. Total ketone bodies were determined colorimetrically after oxidative hydrolysis to acetone in sealed ampoules by a modification of the 
Table I. Composition ( $\mathrm{g} / \mathrm{kg}$ dry matter) of the fatty acid and the triglyceride diets

Ingredient

Casein*

Maize oil fatty acids

Maize oil

Cellulose $\uparrow$

Mineral mixture

Vitamin mixture§

$\mathrm{Cr}_{2} \mathrm{O}_{3}$

Metabolizable energy (MJ)
Fatty acid diet

217
356
-
342
60
20
5
16.7

Triglyceride diet

217

356

342

60

20

5

$16 \cdot 7$

* Vitamin-free.

+ Alpha cell; Nutritional Biochemicals Corporation, Cleveland, Ohio.

I Supplied per kg diet: United States Pharmacopeia XIV mineral mix, $34.8 \mathrm{~g} ; \mathrm{Ca}\left(\mathrm{H}_{3} \mathrm{PO}_{4}\right) \cdot \mathrm{H}_{2} \mathrm{O}$, $23.4 \mathrm{~g} ; \mathrm{CaCO}_{3}, \mathrm{r} \cdot 6 \mathrm{~g} ; \mathrm{MnSO}_{4} \cdot \mathrm{H}_{2} \mathrm{O}$, $140 \mathrm{mg} ; \mathrm{ZnSO}_{4} \cdot 7 \mathrm{H}_{2} \mathrm{O}$, $50 \mathrm{mg}$; $\mathrm{CuSO}_{4} \cdot 5 \mathrm{H}_{2} \mathrm{O}$, $10 \mathrm{mg}$.

\& Mixed in cellulose; supplied $(\mathrm{mg} / \mathrm{kg})$ choline chloride, 2000; nicotinamide, 200; calcium pantothenate, IOO; DL- $\alpha$-tocopherol, 40 ; riboflavin, I 5 ; pyridoxine hydrochloride , 15 ; thiamin hydrochloride, Io; pteroylglutamic acid, 3 ; biotin, I; 2 -methyl-1,4-napthaquinone, 0.6 ; cyanocobalamin, 0.02 ; butylated hydroxytoluene, roo; retinol equivalent, $2 \cdot 16$; and cholecalciferol, $0^{\circ} 03$.

method of Peden (1964). Liver glycogen was determined colorimetrically by the anthrone method after hydrolysis of the fresh samples in KOH ( $300 \mathrm{~g} / \mathrm{l}$ ) (Hassid \& Abraham, 1957). $\mathrm{Cr}_{2} \mathrm{O}_{3}$ was measured colorimetrically after oxidation to dichromate (Hill \& Anderson, 1958). N content of the diet was determined by the macro-Kjeldahl method. Protein efficiency ratios (PER) were calculated from the values for individual weight gain and food consumption.

The results from Expts $\mathrm{I}$ and 2 were combined and significant differences between mean values for each variable were checked by analysis of variance (Snedecor, 1957). Results from Expts 3 to 5 , as well as 6, were treated similarly.

\section{RESULTS}

Table 2 shows the results of Expts I and 2 relating to weight gain, food consumption, plasma glucosc and total ketone bodies, liver glycogen, and PER of rats fed $a d$ lib. on the fatty acid and on the triglyceride diets. The results for rats meal-fed on the same diets in Expts 3-5 are given in Table 3. The results of Expt 6, in which the effect of the fatty acid diet on the concentration of liver glycogen and on the percentage retention of the meal in the stomach 2, 4 and $6 \mathrm{~h}$ after the beginning of feeding was investigated, are shown in Fig. I.

In Expts I and 2, the fatty acid diet produced results that were, with one exception, similar to those found when the triglyceride diet was given ad lib. (Table 2). The exception was the significantly ( $5 \%$ level of probability) lowcr food consumption of rats fed on the triglyceride diet, compared with that of rats fod on the fatty acid diet.

In the meal-feeding experiment the weight gains, food consumption and PER of the rats given the fatty acid diet in Expts $3^{-} 5$ were significantly lower ( $1 \%$ level of probability) than those of the rats fed on the triglyceride diet (Table 3 ). Also, the plasma 
Table 2. Mean weight increase, food consumption, concentrations of glucose and total ketone bodies in plasma, concentration of liver glycogen, and protein efficiency ratio (PER) of rats fed ad lib. on the fatty acid and the triglyceride diets

(Mean values with their standard errors for groups of ten rats; experimental period of $\mathrm{I} 7 \mathrm{~d}$ )

\begin{tabular}{|c|c|c|c|c|}
\hline & $\begin{array}{c}\text { Fatty acid } \\
\text { diet }\end{array}$ & $\begin{array}{c}\text { Triglyceride } \\
\text { diet }\end{array}$ & SE & Significance \\
\hline Weight increaset $(\mathrm{g})$ & $86 \cdot 0$ & $92 \cdot 5$ & 4.02 & NS \\
\hline $\begin{array}{l}\text { Food consumed }(\mathrm{g}) \\
\text { Plasma glucose }(\mathrm{g} / \mathrm{l})\end{array}$ & $\begin{array}{r}300.0 \\
1.64\end{array}$ & $\begin{array}{l}279 \cdot 5 \\
I \cdot 54\end{array}$ & $\begin{array}{l}6.61 \\
0.051\end{array}$ & NS \\
\hline Plasma ketones (mg/l) & 80.0 & 80.0 & $6 \cdot 33$ & NS \\
\hline Liver glycogen $(\mathrm{g} / \mathrm{kg})$ & 26.0 & $27 \cdot 5$ & I.05 & NS \\
\hline PER & $I \cdot 5$ & $x \cdot 7$ & 0.09 & NS \\
\hline \multicolumn{5}{|c|}{$\begin{array}{l}\text { NS, not significant. } \\
* P<0.05 . \\
+ \text { Mean initial weight, } 1 \text { Io g. }\end{array}$} \\
\hline
\end{tabular}

Table 3. Mean weight increase, food consumption, concentrations of glucose and total ketone bodies in plasma, concentration of liver glycogen, and protein efficiency ratio (PER) of rats meal-fed on the fatty acid and triglyceride diets

(Mean value with standard error for groups of twenty rats; experimental period of $19 \mathrm{~d}$ )

\begin{tabular}{|c|c|c|c|c|}
\hline & $\begin{array}{c}\text { Fatty acid } \\
\text { diet }\end{array}$ & $\begin{array}{c}\text { Triglyceride } \\
\text { diet }\end{array}$ & SE & Significance \\
\hline Weight increase $\uparrow(\mathrm{g})$ & $27 \cdot 7$ & 557 & $3 \cdot 45$ & ** \\
\hline Food consumed $(\mathrm{g})$ & $x 62 \cdot 0$ & $177 \cdot 0$ & 5.98 & ** \\
\hline Plasma glucose $(\mathrm{g} / 1)$ & I.4I & $I \cdot 50$ & 0.035 & $* *$ \\
\hline Plasma ketones (mg/1) & $160 \cdot 0$ & $150 \%$ & $8 \cdot 93$ & NS \\
\hline Liver glycogen $(\mathrm{g} / \mathrm{kg})$ & $16 \cdot 0$ & 21.0 & $\mathrm{I} \cdot 45$ & *** \\
\hline PER & 0.8 & $x \cdot 6$ & 0.08 & ** \\
\hline
\end{tabular}

glucose and liver glycogen concentrations in rats meal-fed on the fatty acid diet were significantly lower ( $\mathrm{c} \%$ level of probability) than those of the rats meal-fed on the triglyceride diet (Table 3). The differences in the concentrations of total ketone bodies in plasma were not significant (Table 3 ). In comparison with liver glycogen concentration as measured at the end of the meal period, the liver glycogen concentrations of rats meal-fed on the fatty acid diet were significantly higher (at the $5 \%$ level of probability) $6 \mathrm{~h}$ after the beginning of feeding and those of the rats given the triglyceride diet were significantly higher (at the $5 \%$ level of probability) 4 and $6 \mathrm{~h}$ after the beginning of feeding (Fig. I). The difference in the concentrations of liver glycogen and the extent of meal retention in the stomachs of animals meal-fed on the fatty acid or on the triglyceride diet did not become significant (at the $5 \%$ level of probability) until $6 \mathrm{~h}$ after the beginning of feeding (Fig. I). 

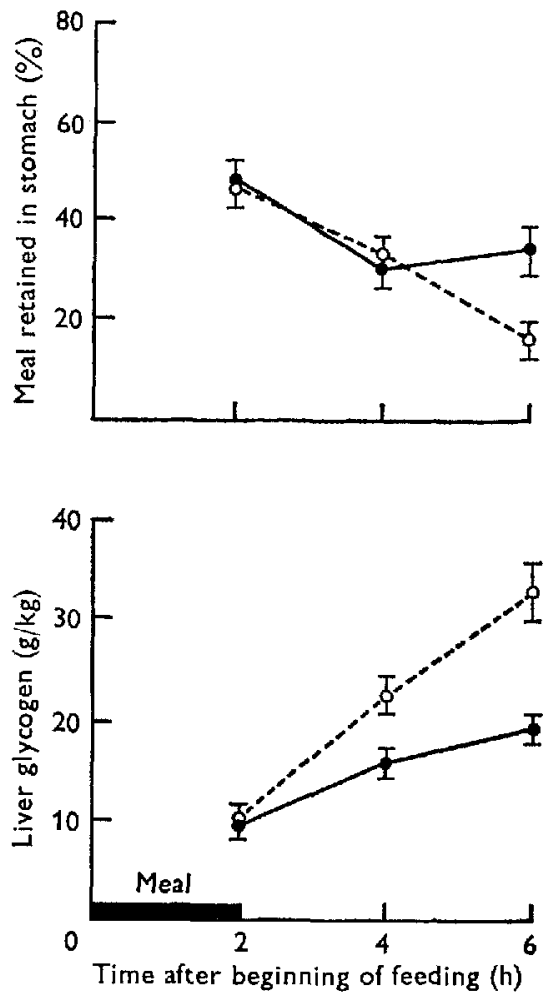

Fig. x. Changes in the concentration of liver glycogen and the amount of the meal retained in the stomach 2,4 and $6 \mathrm{~h}$ after the beginning of feeding on the fatty acid (- - ) or the triglyceride $(\mathrm{O}-\mathrm{O})$ diet. Each point represents the mean value with its standard error for eight rats.

\section{DISCUSSION}

The difference between the responses to dietary carbohydrate deficiency of the rats fed $a d l i b$, and the meal-fed rats is the most striking finding of this study. When rats were fed $a d l i b$. on the fatty acid diet they grew as well as those fed on the triglyceride diet (Table 2). However, rats of similar weight and age when meal-fed on the fatty acid diet grew significantly less than those fed on the triglyceride diet (Table 3). Moreover, rats that were fed $a d l i b$. on the fatty acid diet consumed more food than those fed on the triglyceride diet and, in all experiments in which meal-feeding was used, the rats fed on the fatty acid diet consumed less food than those receiving the triglyceride diet. With both types of feeding the fatty acid diet was utilized less efficiently than the triglyceride diet. Meal-feeding, however, greatly intensified the deleterious effects of the fatty acid diet. Since the fatty acid and the triglyceride diets were isonitrogenous and isoenergetic it can be assumed that the protein of the fatty acid diet was used for purposes other than growth. Presumably, some of the protein of the fatty acid diet was used for synthesis of glucose and glycerol-3-phosphate. Except in cases of extreme starvation, glucose is the main, if not the only, source of energy for the brain in man and presumably also in the rat (Owen, Morgan, Kemp, Sullivan, Herrera \& Cahill, I967). The increase in liver glycogen concentration of rats meal-fed 
on the fatty acid diet, although significant and indicative of net glucose synthesis from dietary protein, did not equal the increase in the group fed on the triglyceride diet (Fig. I). Also, glycerol-3-phosphate is required for the formation of triglycerides in the process of fatty acid absorption (Senior, 1964; Isselbacher, 1965). Any delay in fatty acid absorption may cause a delay in stomach emptying. This is due to the intense inhibitory effect of the presence of fat in the upper intestine due to the probable release of enterogastrone as well as nervous reflexes which are inhibitory to stomach mobility and secretion (Hunt \& Knox, 1968). On this basis, the rate of stomach emptying could be taken as a measure of fatty acid absorption occurring distally in the small intestine and thus of glycerol-3-phosphate synthesis from dietary protein. In Expt 6, the amount of meal retained in the stomach 2 and $4 \mathrm{~h}$ after the beginning of feeding was the same for the groups given the triglyceride and fatty acid diets. The animals meal-fed on the fatty acid diet, however, had retained significantly more meal in their stomach $6 \mathrm{~h}$ after the beginning of feeding (Fig. $\mathrm{r}$ ). This was probably due to the limited supply of glycerol-3-phosphate for those fed on the fatty acid diet. The synthesis of glucose and glycerol-3-phosphate from the dietary protein in rats receiving the fatty acid diet limited the amount of protein available for growth, which consequently suffered. Also the amount of synthesized glycerol-3-phosphate was probably not sufficient to effect complete absorption of the fatty acids, of which some may have been excreted. This is possibly why rats meal-fed on the fatty acids diet stored less of the ingested energy in the form of weight increase.

It was not so when rats given the triglyceride diet were meal-fed, probably because the fatty acids in the diet were already present in the form of triglycerides. The presence of the glycerol moiety in the maize oil of the triglyceride diet renders the net synthesis of glycerol-3-phosphate from dietary protein unnecessary for the process of lipid absorption. Moreover, the amount of glycerol in the triglyceride portion of the diet must have been used for the synthesis of glucose in an amount sufficient to spare the dietary protein for growth. This was also apparent from the PER values, which showed, in comparison with those for rats fed on the fatty acid diet, significantly higher values for animals meal-fed on the triglyceride diet. In all experiments in which the rats were meal-fed, the triglyceride diet produced significantly higher plasma glucose and liver glycogen concentrations than were observed in animals given the fatty acid diet. This is another indication of the essential part that glycerol plays under meal-feeding conditions in the support of high plasma glucose and liver glycogen concentrations.

The low plasma glucose and liver glycogen concentrations associated with mealfeeding with the fatty acid diet were not evident when the diet was consumed ad lib. (Table 2). Further, rats fed $a d$ lib. on the fatty acid diet had the same weight gain and PER as those fed on the triglyceride diet. To accomplish this, rats fed on the fatty acid diet consumed more food than those fed on the triglyceride diet. Thus, one could assume that the utilization of the fatty acid diet was somewhat less efficient than that of the triglyceride diet. This reduced efficiency, however, was nowhere near the level observed when the fatty acid diet was meal-fed since it was reflected only by a higher food consumption for the support of the same weight gain and not by the other 
criteria tested. It is interesting to note that, in order to maintain their optimum weight increase, rats fed ad lib. on the fatty acid diet adjusted by increasing their food consumption.

The failure of the rats fed $a d$ lib. on the fatty acid diet to produce signs of carbohydrate deficiency, when compared with those given the control diet, does not agree with the results of Akrabawi \& Hill (1970) and Goldberg (1971). This disagreement may be because, in their studies, Akrabawi \& Hill (I970) used a diet containing ${ }^{5}{ }^{\circ} \mathrm{g}$ protein $/ \mathrm{kg}$, and Goldberg (I97I) used rats weighing 30-40 g, in comparison with our diet containing $200 \mathrm{~g}$ protein $/ \mathrm{kg}$ and rats weighing $\mathrm{I}$ ro g. The results of our study show that, when rats are meal-fed, the removal of glyccrol from a diet in which all the non-protein energy is derived from maize oil reduces weight gain, decreases plasma glucose and liver glycogen concentrations, depresses the PER and increases the extent of meal retention in the stomach.

\section{REFERENCES}

Akrabawi, S. \& Hill, F. W. (1970). Fedn Proc. Fedn Am. Socs exp. Biol. 29, 764 Abstr.

Allred, J. B. (1969), ₹. Nutr. 99, гог.

Allred, J. B. \& Roehrig, K. L. (1970). F. Nutr. roo, 6 I 5.

Brambila, S. \& Hill, F. W. (1966). F. Nutr. 88, 84 .

Brambila, S. \& Hill, F. W. (1967). F. Nutr. 9r, 261.

Goldberg, A. (1971). \%. Nutr. 101, 693 .

Hassid, W. Z. \& Abraham, S. (1957). Meth. Enzym. 3, 34 .

Hill, F. W. \& Anderson, D. L. (1958). F. Nutr. 64, 587.

Hunt, J. N. \& Knox, M. T. (1968). In Handboak of Physiology Sect. 6 Alimentary Canal Vol. 4, p. 1917 [C. C. Code, editor]. Washington, DC: American Physiological Society.

Isselbacher, K. J. (1965). Fedn Proc. Fedn Am. Socs exp. Biol. 24, I6.

Leveille, G. A. (1967). F. Nutr. 91, 267.

Leveille, G. A. \& Hanson, R. W. (I965). Can. F. Physiol. Pharmac, 43, 857.

Leveille, G. A. \& Hanson, R. W. (I 966). Can. F. Physiol. Pharmac. 44, 275.

Owen, O. E., Morgan, A. P., Kemp, H. G., Sullivan, J. M., Herrera, M. G. \& Cahill, G. F. Jr (1967). F. clin. Invest. 46, 1589 .

Peden, V. H. (1964). F. Lab. clin. Med. 63, 332.

Renner, R. \& Elcombe, A. M. (1964). F. Nutr. 84, 327.

Senior, J. R. (1964). F. Lipid Res. 5, 495.

Snedecor, G. W. (1957). Statistical Methods Applied to Experiments in Agriculture and Biology 5 th ed. Ames, Iowa: Iowa State University Press. 